\title{
Analisis Financial Statement Fraud Menggunakan Beneish M-Score Model Pada Perusahaan Pertambangan Yang Terdaftar Di Bursa Efek Indonesia
}

\author{
(Analysis of Financial Statement Fraud Using Beneish M-Score Model for Mining \\ Companies Listed in Indonesian Stock Exchange)
}

\author{
Fitri Aulia Rachmi*, Djoko Supatmoko, Bunga Maharani \\ Jurusan Akuntansi, Fakultas Ekonomi dan Bisnis, Universitas Jember (UNEJ) \\ Jln. Kalimantan 37, Jember 68121 \\ E-mail: fitrirachmi82@gmail.com
}

\begin{abstract}
Abstrak
Penelitian ini bertujuan menguji dan menganalisis penggunaan model Beneish M-Score untuk mendeteksi financial statement fraud. Data yang digunakan adalah data sekunder berupa laporan keuangan perusahaan pertambangan terbuka di Indonesia. Metode penelitian yang digunakan adalah metode kuantitatif dengan analisis diskriminan. Metode analisis diskriminan digunakan untuk menganalisa hubungan antara model Beneish M-Score dengan financial statement fraud dengan cara melihat faktor atau variabel mana yang secara nyata dapat mempengaruhi variabel dependen. Pengaplikasian analisis diskriminan dilakukan untuk menguji variabel independen manakah yang secara akurat dapat membedakan sampel laporan keuangan yang diduga telah dimanipulasi dan laporan keuangan yang diduga tidak dimanipulasi. Hasil penelitian menunjukkan bahwa variabel yang mampu membedakan sampel laporan keuangan yang diduga telah dimanipulasi dan diduga tidak dimanipulasi adalah variabel Days Sales Receivable Index (DSRI), Gross Margin Index (GMI), Sales Growth Index (SGI), dan Total Accrual to Total Asset (TATA) sementara variabel Asset Quality Index (AQI), Depreciation Index (DEPI), Sales and General Administration Expenses Index (SGAI), Leverage Index (LVGI) terbukti tidak mampu membedakan laporan keuangan yang diduga telah dimanipulasi dan diduga tidak dimanipulasi.
\end{abstract}

Kata Kunci: Model Beneish M-Score, financial statement fraud.

\begin{abstract}
This research aimed to test and analyse Beneish M-Score model to detect financial statement fraud. The data used are secondary data from financial report of mining companies in Indonesia. The method used in this research was quantitative method with discriminant analysis. Discriminant analysis method is used to analyse the relationship between Beneish M-Score models and financial statement fraud by observing which factors or variables can significantly affect the dependent variable. The application of discriminant analysis is carried out to test which independent variables can accurately distinguish samples of financial statements that are allegedly manipulated and financial statements that are allegedly not manipulated were the variable Days Sales Receivable Index (DSRI), Gross Margin Index (GMI), Sales Growth Index (SGI), and Total Accrual to Total Asset (TATA) while the variable Asset Quality Index (AQI), Depreciation Index (DEPI), Sales and General Administration Expenses Index (SGAI), Leverage Index (LVGI) proved unable to distinguish financial statements that are allegedly manipulated and financial statements that are allegedly not manipulated.
\end{abstract}

Keywords: Beneish M-Score model, financial statement fraud.

\section{Pendahuluan}

Kecurangan laporan keuangan adalah tindakan kekeliruan secara disengaja berupa penyajian yang salah terhadap jumlah dan pengungkapan dalam laporan keuangan untuk memperoleh keuntungan pribadi dan menyesatkan pengguna laporan keuangan Priantara (2013:35).

Berbagai kasus skandal akuntansi yang terjadi baik pada perusahaan dalam negeri maupun perusahaan skala multinasional masih menjadi isu yang banyak diperhatikan dan diperbincangkan masyarakat luas. Di Indonesia sendiri, pernah muncul skandal akuntansi PT. Kimia Farma pada tahun 2001 yang terbukti melebihsajikan penjualan dan persediaan sehingga mengakibatkan nilai laba bersih menjadi lebih tinggi.

Berdasarkan data Report the Nation of Fraud, diketahui bahwa skema kecurangan laporan keuangan ini memiliki dampak kerugian terbesar namun hanya sedikit yang terungkap karena pelaku nya adalah jajaran eksekutif perusahaan. Terjadinya kecurangan yang tidak dapat dideteksi, dapat memberikan efek merugikan bagi pengguna laporan keuangan. Tindakan manipulasi laporan keuangan ini dilakukan untuk memperoleh feedback positif dari investor dan kreditor. Oleh karena itu, pencegahan dan pendeteksian dini perlu dilakukan untuk meminimalisir praktek kecurangan yang dapat merugikan berbagai pihak dan menghambat pemanfaatan sumber daya.

Dalam berbagai penelitian terkait fraud, terdapat satu alat analisis yang bekerja cukup baik untuk mendeteksi laporan keuangan perusahaan yang dimanipulasi dan laporan keuangan perusahaan yang tidak dimanipulasi yaitu model Beneish M-Score yang dipopulerkan oleh Messod D. Beneish.

\footnotetext{
* Corresponding author
} 
Beneish mengembangkan sebuah metode untuk mengkaji perbedaan kuantitatif antara perusahaan publik yang melakukan manipulasi laporan keuangan dan perusahaan yang tidak melakukan nya. Penelitian tersebut menggunakan 8 rasio indeks yang menghasilkan sebuah model yang dikenal dengan nama Beneish M-Score. Beneish M-Score adalah sebuah model analisis data statisik untuk rasio keuangan yang dihitung menggunakan data akuntansi perusahaan tertentu untuk memeriksa adanya kemungkinan perusahaan melaporkan laba yang telah dimanipulasi. Menurut Widodo et al. (2017) Beneish M-Score merupakan analisis rasio yang dapat mengidentifikasi kemungkinan terjadinya kecurangan dan membantu para CFE (Certified Fraud Examiner) untuk mendeteksi tanda-tanda manipulasi.

Beneish menemukan fakta bahwa laporan keuangan yang dimanipulasi biasanya melebih-lebihkan laba dengan merekam pendapatan fiktif dan pendapatan diterima dimuka, merekam persediaan fiktif dan penyertaan modal yang tidak akurat. Bukti-bukti menunjukkan kemungkinan terjadinya manipulasi ditandai dengan peningkatan piutang, memburuknya margin laba kotor, penurunan kualitas aset, pertumbuhan penjualan, dan peningkatan akrual. Terdapat 8 rasio indeks Beneish M-Score yang dapat digunakan untuk mendeteksi fraud diantaranya Days Sales in Receivable Index (DSRI), Gross Margin Index (GMI), Asset Quality Index (AQI), Sales Growth Index (SGI), Depreciation Index (DEPI), Sales General and Administrative Index (SGAI), Leverage Index (LVGI) dan Total Accruals to Total Assets Index (TATA).

Hasil penelitian Beneish menunjukkan bahwa $76 \%$ dari sampel telah melakukan manipulasi terhadap laporan keuangan nya. Beneish mengungkapkan bahwa variabelvariabel yang signifikan dalam mendeteksi kemungkinan adanya manipulasi adalah 5 dari total 8 variabel yang telah disebutkan yaitu variabel DSRI, GMI, AQI, SGI, dan TATA sementara koefisien pada leverage, depresiasi dan biaya administrasi penjualan tidak signifikan atau tidak pasti berkaitan dengan manipulasi.

Penggunaan rasio yang dikembangkan oleh Beneish (1999) telah digunakan untuk berbagai penelitian di berbagai belahan dunia dengan hasil yang bervariasi. Penelitian yang menguji keakuratan model Beneish adalah penelitian Roxas (2008) dengan menggunakan sampel perusahaan yang terbukti melakukan pelanggaran prinsip akuntansi oleh Badan Akuntansi dan Penegakan Auditing di Amerika Serikat. Hasil penelitian Roxas (2008) menyatakan variabel Beneish M-Score yang signifikan dalam memprediksi indikasi kecurangan meliputi variabel DSRI, variabel GMI, variabel $\mathrm{AQI}$, variabel SGI, dan variabel DEPI dengan presentase keakuratan sebesar $77 \%$.

Hasil penelitian Tarjo \& Herawati (2015) mengungkapkan bahwa model Beneish M-Score secara keseluruhan dapat mendeteksi kecurangan laporan keuangan. Indeks margin laba kotor, indeks depresiasi, indeks penjualan dan administrasi umum dan indeks total akrual merupakan variabel yang signifikan mampu memetakan laporan keuangan yang dimanipulasi dan tidak dimanipulasi. Sementara indeks penjualan, indeks kualitas aset dan indeks leverage secara statistik tidak signifikan dalam mendeteksi kecurangan laporan keuangan. Hasil penelitian tersebut berbeda dengan penelitian Hantono (2018) yang menyimpulkan bahwa seluruh variabel Beneish tidak memiliki pengaruh terhadap kecurangan laporan keuangan dan tidak mampu mendeteksi potensi terjadinya kecurangan laporan keuangan. Perbedaan hasil penelitian terdahulu menyebabkan peneliti ingin meneliti apakah variabelvariabel Beneish M-Score mampu membedakan laporan keuangan yang diduga telah dimanipulasi dan diduga tidak dimanipulasi dengan analisis diskriminan.

Association of Certified Fraud Examiners (2011) mendefinisikan kecurangan sebagai perbuatan melawan hukum yang dilakukan dengan sengaja untuk tujuan tertentu dengan cara memanipulasi atau memberikan memberikan laporan yang keliru kepada pihak lain dan menyalahgunakan sumberdaya atau asset milik pihak lain yang dilakukan orangorang dari dalam atau luar organisasi untuk memperoleh keuntungan pribadi maupun kelompok baik secara langsung maupun tidak langsung dan dapat merugikan pihak lain.

ACFE mengklasifikasikan kecurangan (fraud) dalam tiga tipologi yang dikenal dengan istilah "fraud tree" berdasarkan jenis perbuatan, yaitu: 1). Penyimpangan atas Aset (Asset Missapropriation), 2) Rekayasa Laporan Keuangan (Fraudulent Financial Statement), 3) Korupsi (Corruption)

\section{Hipotesis}

H1: Variabel Days Sales Receivable Index mampu membedakan laporan keuangan yang diduga telah dimanipulasi dan laporan keuangan yang diduga tidak dimanipulasi.

H2: Variabel Gross Margin Index mampu membedakan laporan keuangan yang diduga telah dimanipulasi dan laporan keuangan yang diduga tidak dimanipulasi.

H3: Variabel Asset Quality Index mampu membedakan laporan keuangan yang diduga telah dimanipulasi dan laporan keuangan yang diduga tidak dimanipulasi.

H4: Variabel Sales Growth Index mampu membedakan laporan keuangan yang diduga telah dimanipulasi dan laporan keuangan yang diduga tidak dimanipulasi.

H5: Variabel Depreciation Index tidak mampu membedakan laporan keuangan yang diduga telah dimanipulasi dan laporan keuangan yang diduga tidak dimanipulasi.

H6: Variabel Sales General and Administrative Expenses Index mampu membedakan laporan keuangan yang diduga telah dimanipulasi dan laporan keuangan yang diduga tidak dimanipulasi.

H7: Variabel Leverage Index mampu membedakan laporan keuangan yang diduga telah dimanipulasi dan laporan keuangan yang diduga tidak dimanipulasi.

H8: Variabel Total Accrual to Total Assets mampu membedakan laporan keuangan yang diduga telah dimanipulasi dan laporan keuangan yang diduga tidak dimanipulasi.

\section{Metode}

\section{Desain Penelitian}

Desain penelitian ini adalah penelitian kuantitatif. Menurut Indriantoro \& Supomo (2014:12) penelitian kuantitatif menekankan pada pengujian teori melalui pengukuran 
variabel-variabel penelitian dengan angka dan menganalisis data dari hasil pengukuran tersebut menggunakan prosedur statistik. Penelitian ini bertujuan menguji dan menganalisis variabel-variabel independen yaitu DSRI, GMI, AQI, SGI, DEPI, SGAI, LVGI, dan TATA terhadap financial statement fraud dengan menggunakan model Beneish M-Score.

\section{Jenis dan Sumber Data}

Data yang digunakan dalam penelitian berikut adalah data sekunder yang diperoleh dari laporan keuangan disertai laporan auditor independen. Penelitian ini menggunakan data sekunder dengan pertimbangan bahwa data lebih mudah diperoleh, tidak membutuhkan biaya yang besar, data bersifat akurat serta memiliki informasi yang lengkap sesuai kebutuhan penelitian.

Pengumpulan data dilakukan dengan cara melakukan penelusuran dan pencatatan informasi yang diperlukan pada data sekunder berupa laporan keuangan yang telah di audit pada perusahaan pertambangan tahun 2014-2017 di Bursa Efek Indonesia. Data tersebut diperoleh dari website resmi PT Bursa Efek Indonesia (www.idx.com) atau website resmi perusahaan.

\section{Populasi dan Sampel}

Populasi dari penelitian ini adalah perusahaan pertambangan yang terdaftar di Bursa Efek Indonesia pada tahun pengamatan 2015-2017. Sampel yang dipilih menggunakan metode purposive sampling. Metode purposive sampling merupakan pemilihan sampel secara tidak acak dengan kriteria dan pertumbangan tertentu sesuai dengan tujuan dan masalah penelitian Indriantoro \& Supomo (2014:125). Kriteria penetuan sampel dalam penelitian ini adalah sebagai berikut:

a) Perusahaan pertambangan yang terdaftar di Bursa Efek Indonesia dan tidak mengalami delisting selama periode 2015-2017.

b) Perusahaan pertambangan yang mempublikasikan laporan keuangan teraudit berturut-turut tahun 2015-2017 di website resmi BEI atau website resmi perusahaan.

c) Variabel-variabel yang diteliti tersedia dengan lengkap dalam laporan keuangan tahun 2015- 2017.

\section{Definisi Operasional dan Pengukuran Variabel}

1. Days Sales Receivable Index (DSRI)

$$
\text { DSRI }=\frac{\text { Piutang Usaha }(t) / \text { Penjualan }(t)}{\text { Piutang Usaha }(t-1) / \text { Penjualan }(t-1)}
$$

2. Gross Margin Index (GMI)

$$
\mathrm{GMI}=\frac{\text { Laba Kotor }(t-1) / \text { Penjualan }(t-1)}{\text { Laba Kotor }(t) / \text { Penjualan }(t)}
$$

3. Asset Quality Index (AQI)

$$
\text { AQI }=\frac{\frac{1-\text { Aset lancar }(t)+\text { Aset Tetap }(t)}{\text { Total Aset }(t)}}{\frac{1-\text { Aset lancar }(t-1)+\text { Aset Tetap }(t-1)}{\text { Total Aset }(t-1)}}
$$

4 Sales Growth Index (SGI)

SGI $=\frac{\text { Penjualan }(t)}{\text { Penjualan }(t-1)}$

5. Depreciation Index (DEPI)

$$
\text { DEPI }=\frac{\frac{\text { Depresiasi }(t-1)}{\text { Depresiasi }(t-1)+\text { Aset Tetap }(t-1)}}{\text { Depresiasi }(t)}
$$

6. Sales General Administration Expenses Index (SGAI)

$$
\text { SGAI }=\frac{\frac{\text { Biaya Penjualan dan Administrasi }(t)}{\text { Penjualan }(t)}}{\frac{\text { Biaya Penjualandan Administrasi }(t-1)}{\text { Penjualan }(t-1)}}
$$

7. Leverage Index (LVGI)

$\mathrm{LVGI}=\frac{\frac{\text { Total Kewajiban }(t)}{\text { Total Aset }(t)}}{\frac{\text { Total Kewajiban }(t-1)}{\text { Total Aset }(t-1)}}$

8. Total Acrual to Total Asset (TATA)

TATA $=\frac{\text { EAT }(t)-\text { Arus Kas Aktivitas Operasi }(t)}{\text { Total Aset }(t)}$

Setelah ke delapan rasio tersebut diperhitungkan, kemudian hasil nya diformulasikan ke dalam rumus Beneish M-Score Model sebagai berikut:

\section{M-Score $=-4,48+0,920$ DSRI + 0,528 GMI + 0,404 AQI + 0,892 SGI + 0,115 DEPI - 0,172 SGAI - 0,327 LVGI + 4,697 TATA}

Jika Beneish M-Score lebih besar dari -2,22 maka laporan keuangan terindikasi telah dimanipulasi. Sebaliknya jika nilai Beneish M-Score lebih kecil dari -2,22 maka laporan keuangan terindikasi tidak dimanipulasi.

\section{Metode Analisis Data}

Analisis data menggunakan analisis diskriminan dengan software SPSS 23 untuk menguji variabel yang signifikan dapat memetakan laporan keuangan yang diduga telah dimanipulasi dan yang diduga tidak dimanipulasi.

\section{Hasil dan Pembahasan}

\section{Hasil}

\section{Hasil Statistik Deskriptif}

Analisis statistik deskriptif digunakan untuk menggambarkan karakteristik variabel-variabel dalam penelitian. Karakteristik yang dimunculkan adalah nilai rata- rata, nilai tengah, standar deviasi, nilai maksimum, nilai minimum dll. Statistik deskripstif mentransformasikan data penelitian kemudian menyajikan data tersebut dalam bentuk tabulasi. Data yang diperoleh kemudian disusun dalam bentuk tabel dan dijabarkan dengan kalimat penjelas. Analisis statistik 
deskriptif dalam penelitian ini digunakan untuk menggambarkan karakter delapan variabel bebas DSRI, GMI, AQI, SGI, DEPI, SGAI, LVGI, dan TATA.

Tabel 1. Hasil Uji Statistik Deskriptif

\begin{tabular}{|l|c|c|c|c|c|}
\hline & N & Minimum & Maksimum & Rata-rata & Std. Deviation \\
\hline DSRI & 72 & 0,1 & 2,68 & 1,1050 & 0,51689 \\
\hline GMI & 72 & $-0,69$ & 5,61 & 1,0559 & 0,93042 \\
\hline AQI & 72 & 0,57 & 2,53 & 1,0295 & 0,25482 \\
\hline SGI & 72 & 0,41 & 1,98 & 1,0405 & 0,32321 \\
\hline DEPI & 72 & 0,73 & 2,47 & 0,9761 & 0,22120 \\
SGAI & 72 & 0,61 & 2,25 & 1,0539 & 0,32836 \\
\hline LVGI & 72 & 0,53 & 1,87 & 0,9654 & 0,21431 \\
\hline TATA & 72 & $-0,22$ & 0,17 & $-0,0487$ & 0,07473 \\
\hline
\end{tabular}

Berdasarkan tabel 1 diatas, tidak terdapat data yang memiliki nilai ekstrim sehingga asumsi pertama tentang data outlier dalam analisis diskriminan telah terpenuhi.

Tabel 2. Hasil Uji Normalitas

\begin{tabular}{|ll|l|}
\hline & & Unstandardized Residual \\
\hline N & Mean & 72 \\
\hline Normal Parameters $^{2, b}$ & $\begin{array}{l}\text { Std. } \\
\text { Deviation }\end{array}$ &, 26191840 \\
\hline Most Extreme Differences & Absolute &, 058 \\
\cline { 2 - 3 } & Positive &, 057 \\
\hline Test Statistic & Negative &,- 058 \\
\hline Asymp. Sig. (2-tailed) & &, 058 \\
\hline
\end{tabular}

Berdasarkan Uji Normalitas Kolmogorov-Smirnov (K-S), hasil test menunjukkan bahwa data telah terdistribusi normal karena skor $0,200>0,05$. Dengan demikian, asumsi normalitas data dalam analisis diskriminan telah terpenuhi.

Tabel 3. Test of Equality Group Means

\begin{tabular}{|c|c|c|c|c|c|}
\hline & Wilks' Lambda & F & df1 & df2 & Sig. \\
\hline DSRI & 0,809 & 16,508 & 1 & 70 & 0,000 \\
\hline GMI & 0,905 & 7,376 & 1 & 70 & 0,008 \\
\hline AQI & 0,987 & 0,933 & 1 & 70 & 0,337 \\
\hline SGI & 0,977 & 5,687 & 1 & 70 & 0,020 \\
\hline DEPI & 0,925 & 1,647 & 1 & 70 & 0,204 \\
\hline SGAI & 0,973 & 1,962 & 1 & 70 & 0,166 \\
\hline LVGI & 1,000 & 0,004 & 1 & 70 & 0,948 \\
\hline TATA & 0,755 & 22,696 & 1 & 70 & 0,000 \\
\hline
\end{tabular}

Keputusan yang diberlakukan untuk hasil tes tersebut dapat diambil dengan melihat angka signifikan. Jika angka sig. < 0,05 artinya variabel memang berbeda untuk kelompok diduga telah dimanipulasi dan diduga tidak dimanipulasi. Melalui tabel 3 di atas, dapat diketahui bahwa variabel DSRI, variabel GMI, variabel SGI, dan variabel TATA memiliki angka sig. $<0,05$ yang berarti variabel- variabel tersebut mempunyai pengaruh yang bermakna terhadap variabel dependen. Adapun variabel AQI, DEPI, SGAI, dan LVGI yang memiliki nilai sig. $>0,05$ tidak lolos uji dan otomatis dikeluarkan dari pembentukan fungsi diskriminan.
Tabel 4. Tabel Entered

\begin{tabular}{|c|c|c|c|c|c|c|c|}
\hline \multicolumn{2}{|c|}{ Variables Entered } \\
\hline \multirow{2}{*}{ Step } & \multirow{2}{*}{ Entered } & \multirow{5}{|c|}{ Min. D Squared } \\
\cline { 5 - 8 } & & Statistic & $\begin{array}{c}\text { Between } \\
\text { Groups }\end{array}$ & \multicolumn{5}{|c|}{ Exact F } \\
\cline { 5 - 8 } & & & 0 and 1 & 22,696 & 1 & 70,000 & $9,947 \mathrm{E}-6$ \\
\hline 1 & TATA & 1,526 & 0 dfistic & df1 & df2 & Sig. \\
\hline 2 & GMI & 3,161 & 0 and 1 & 23,174 & 2 & 69,000 & $1,999 \mathrm{E}-8$ \\
\hline 3 & DSRI & 6,059 & 0 and 1 & 29,186 & 3 & 68,000 & $3,048 \mathrm{E}-12$ \\
\hline 4 & SGI & 7,914 & 0 and 1 & 28,168 & 4 & 67,000 & $9,796 \mathrm{E}-14$ \\
\hline
\end{tabular}

Sumber : Data Sekunder yang diolah dengan SPSS 23.

Tabel 4. menunjukkan variabel mana saja yang bisa dimasukkan (entered) dan digunakan untuk membentuk fungsi diksriminan. Dari delapan variabel Beneish yang tersedia, hanya variabel TATA, GMI, DSRI dan SGI yang dianggap mampu membedakan kelompok diduga telah dimanipulasi dan diduga tidak dimanipulasi sedangkan variabel AQI, DEPI, SGAI, dan LVGI dieliminasi dalam persamaan fungsi diskriminan.

Pada tahap pertama, angka $\mathrm{F}$ hitung variabel TATA memiliki nilai signifikan 9,947E-6 atau 0,00000947. Pada tahap kedua dengan variabel independen yang telah berkurang satu, diketahui bahwa variabel GMI memiliki nilai $\mathrm{F}$ signifikan terbesar kedua yaitu 1,999E-8 atau 0,0000000199. Selanjutnya pada tahap ketiga ketika variabel telah berkurang dua, angka $\mathrm{F}$ hitung variabel DSRI menempati urutan ketiga dengan nilai 3,048E-12 atau 0,0000000000030148. Variabel SGI menempati urutan terakhir dalam variabel yang layak dimasukkan ke dalam fungsi diskriminan dengan nilai signifikan 9,796E-14 atau sebesar 0,00000000000009796. Keempat variabel tersebut memiliki angka signifikan dibawah 0,05 sehingga dapat disimpulkan bahwa variabel TATA, GMI, DSRI dan SGI dapat mendiskriminasi atau membedakan laporan keuangan yang dimanipulasi dan tidak dimanipulasi berdasarkan pengelompokkan Beneish M-Score Model.

Tabel 5. Variabel Removed

\begin{tabular}{|c|c|c|c|c|c|c|}
\hline \multicolumn{2}{|r|}{ Step } & Tolerance & $\begin{array}{c}\text { Min. } \\
\text { Tolerance }\end{array}$ & $\begin{array}{c}\text { Sig. of F to } \\
\text { Enter }\end{array}$ & $\begin{array}{l}\text { Min. D } \\
\text { Square }\end{array}$ & $\begin{array}{c}\text { Beetwen } \\
\text { Group }\end{array}$ \\
\hline \multirow[t]{4}{*}{4} & AQI & 0,924 & 0,636 & 0,319 & 8,106 & 0 and 1 \\
\hline & DEPI & 0,866 & 0,608 & 0,056 & 8,636 & 0 and 1 \\
\hline & SGAI & 0,827 & 0,650 & 0,137 & 8,346 & 0 and 1 \\
\hline & LVGI & 0,967 & 0,645 & 0,578 & 7,974 & 0 and 1 \\
\hline
\end{tabular}

Tabel 5. menunjukkan variabel yang dikeluarkan dalam analisis karena angka signfikansi nya di atas 0,05. Oleh karena itu, variabel AQI, DEPI, SGAI dan LVGI terbukti tidak dapat mengelompokkan laporan keuangan yang dimanipulasi dan tidak dimanipulasi.

Tahap keempat (step 4) berarti bahwa proses pengeluaran variabel telah berhenti. Berdasarkan tabel 5 diketahui bahwa angka sig. of $\mathrm{F}$ to enter dari variabel AQI, DEPI, SGAI dan LVGI berada di atas 0,05. Dengan demikian, tahap ini merupakan tahap penentuan variabel yang tidak dianalisis lebih lanjut karena sudah tidak ada variabel yang memenuhi persyaratan untuk dimasukkan dalam fungsi diskriminan. 
Tabel 6. Tabel Eigenvalue

\begin{tabular}{|c|c|c|c|c|}
\hline Function & Eigenvalue & \% of Variance & Cumulative \% & $\begin{array}{c}\text { Canonical } \\
\text { Correlation }\end{array}$ \\
\hline 1 & $1,682^{\mathrm{a}}$ & 100,0 & 100,0 &, 792 \\
\hline
\end{tabular}

a. First 1 canonical discriminant functions were used in the analysis.

Berdasarkan tabel 6 diatas, angka yang dijadikan acuan untuk menginterpretasikan hasil pengujian adalah nilai canonical correlation. Canonical correlation digunakan untuk mengukur keeratan hubungan antara kedua kelompok dan fungsi diskriminan dengan skala 0 hingga 1 . Skor canonical correlation yang tercantum pada hasil pengujian menunjukkan angka 0,792. Angka tersebut menandakan bahwa terdapat keeratan hubungan yang cukup tinggi antara kelompok tidak dimanipulasi dan kelompok dimanipulasi dengan fungsi diskriminan yang terbentuk. Menurut Ghozali (2011:204), nilai canonical correlation perlu dikuadratkan dan dikalikan seratus untuk mendapatkan nilai presentase. Jika mengikuti panduan dari Ghozali (2011), akan diperoleh angka presentase sebesar $62,7 \%$. Oleh karena itu dapat disimpulkan bahwa sebesar $62,7 \%$ variasi variabel dependen (Y) dapat dijelaskan oleh variabel independen yang layak dianalisis lebih lanjut yaitu variabel TATA (X8), variabel GMI (X2), variabel DSRI (X1) dan variabel GMI (X4).

Tabel 7. Tabel Wilks' Lambda

\begin{tabular}{|c|c|c|c|c|}
\hline Test of Function(s) & Wilks' Lambda & Chi-square & Df & Sig. \\
\hline 1 &, 373 & 67,078 & 4 &, 000 \\
\hline
\end{tabular}

Tabel wilk's lambda menjelaskan mengenai perbedaan diantara kelompok tidak dimanipulasi (kode 0) dan kelompok dimanipulasi (kode 1). Angka 0,373 yang tercantum di dalam kolom wilks' lambda menunjukkan sebanyak $37,3 \%$ variasi yang tidak dapat dijelaskan oleh empat variabel independen yang lolos uji. Sementara itu angka chi-square sebesar 67,078 dengan sig. di bawah 0,05 menggambarkan perbedaan yang jelas antara kelompok tidak dimanipulasi dan kelompok dimanipulasi.

Tabel 8. Classification Result

\begin{tabular}{|c|c|c|c|c|}
\hline Function & Eigenvalue & $\%$ of Variance & Cumulative \% & $\begin{array}{c}\text { Canonical } \\
\text { Correlation }\end{array}$ \\
\hline 1 & $1,682^{\mathrm{a}}$ & 100,0 & 100,0 &, 792 \\
\hline
\end{tabular}

a. First 1 canonical discriminant functions were used in the analysis.

Tabel 8. menjelaskan seberapa tepat hasil klasifikasi dari persamaan atau fungsi diskriminan dan berapa persen tingkat kesalahan dalam analisis ini. Pada bagian original, terlihat bahwa klasifikasi awal dengan persamaan model Beneish pada grup tidak dimanipulasi adalah 51 sampel. Ketika digunakan fungsi diskriminan yang telah terbentuk untuk menggolongkan sampel, sebanyak 48 sampel (94,1\%) terklasifikasi secara tepat ke dalam kelompok tidak dimanipulasi sedangkan 3 sampel $(5,9 \%)$ justru meleset sehingga digolongkan dalam kelompok dimanipulasi.

\section{Pembahasan}

1. Variabel Days Sales Receivable Index (DSRI) mampu membedakan antara laporan keuangan yang diduga telah dimanipulasi dan diduga tidak dimanipulasi.
Hasil uji analisis diskriminan yang ditampilkan menunjukkan variabel days sales receivable assets (DSRI) memiliki nilai koefisien sebesar 0,374. Variabel DSRI memiliki nilai signifikan sebesar 3,048E-12 atau 0,0000000000030148 yang berada di bawah 0,05. Berdasarkan hasil analisis tersebut, hipotesis pertama dinyatakan diterima karena variabel DSRI secara nyata dapat membedakan laporan keuangan yang telah dimanipulasi dan laporan keuangan yang tidak dimanipulasi.

\section{Variabel Gross Margin Index (GMI) mampu membedakan antara laporan keuangan yang diduga telah dimanipulasi dan diduga tidak dimanipulasi.}

Berdasarkan hasil uji analisis diskriminan, variabel gross margin index (GMI) memiliki angka koefisien sebesar 0,250 dengan nilai signifikan sebesar 1,999E-8 atau 0,0000000199 yang berada di bawah 0,05. Dengan demikian, dapat disimpulkan bahwa hipotesis ke dua dinyatakan diterima karena variabel GMI dapat membedakan laporan keuangan yang telah dimanipulasi dan laporan keuangan yang tidak dimanipulasi.

3. Variabel Assets Quality Index (AQI) tidak mampu membedakan antara laporan keuangan yang diduga telah dimanipulasi dan diduga tidak dimanipulasi.

Hasil uji analisis diskriminan yang ditampilkan menunjukkan variabel asset quality index (AQI) menghasilkan nilai koefisien sebesar -0,239. Variabel AQI memiliki nilai signifikan sebesar 0,319 yang berada di atas 0,05. Dengan demikian, dapat disimpulkan variabel asset quality index (AQI) tidak dapat membedakan laporan keuangan yang telah dimanipulasi dan laporan keuangan yang tidak dimanipulasi. Hasil penelitian tersebut menguatkan penelitian Tarjo (2015:928) karena hasil yang diperoleh sama. Dengan demikian hipotesis ketiga yang mengemukakan bahwa variabel AQI dapat membedakan laporan keuangan yang dimanipulasi dan tidak dimanipulasi dalam penelitian ini dinyatakan ditolak.

4. Variabel Sales Growth Index (SGI) mampu membedakan antara laporan keuangan yang diduga telah dimanipulasi dan diduga tidak dimanipulasi

Hasil analisis yang ditampilkan menunjukkan variabel sales growth index (SGI) memiliki nilai koefisien sebesar 0,118 dengan nilai signifikan sebesar 9,796E-14 atau 0,00000000000009796 yang berada jauh di bawah 0,05. Hasil penelitian ini konsisten dengan penelitian Kusuma (2016:16) yang menjelaskan bahwa variabel SGI dapat membedakan laporan keuangan yang telah dimanipulasi dan laporan keuangan yang tidak dimanipulasi. Dengan demikian hipotesis ke empat yang menyatakan variabel SGI dapat membedakan laporan keuangan yang dimanipulasi dan tidak dimanipulasi dalam penelitian ini diterima.

\section{Variabel Depreciation Index (DEPI) tidak mampu membedakan antara laporan keuangan yang diduga telah dimanipulasi dan diduga tidak dimanipulasi.}

Variabel depreciation index (DEPI) memiliki nilai koefisien sebesar -0,061 dan tingkat signifikan 0,056 di atas 0,05. Hasil penelitian menguatkan Hantono (2018:267) dan penelitian Kusuma (2016:17) tentang ketidakmampuan variabel DEPI dalam memprediksi kecurangan laporan keuangan dengan cara tidak dapat membedakan laporan 
keuangan yang dimanipulasi dan tidak dimanipulasi. Berdasarkan hasil tersebut, hipotesis kelima yang menyatakan bahwa variabel DEPI tidak dapat membedakan laporan keuangan yang telah dimanipulasi dan laporan

6.Variabel Sales General and Administrative Expenses Index (SGAI) tidak mampu membedakan antara laporan keuangan yang diduga telah dimanipulasi dan diduga tidak dimanipulasi.

Pengujian analisis diskriminan untuk variabel SGAI menunjukkan nilai koefisien sebesar -0,084 dengan tingkat signifikan 0,137 di atas 0,05 . Sehubungan dengan hasil tersebut, hipotesis ke enam ditolak karena variabel SGAI tidak dapat membedakan laporan keuangan yang telah dimanipulasi dan laporan keuangan yang tidak dimanipulasi.

7. Variabel Leverage Index (LVGI) tidak mampu membedakan antara laporan keuangan yang diduga telah dimanipulasi dan diduga tidak dimanipulasi.

Variabel leverage index (LVGI) memiliki nilai koefisien sebesar 0,080 dengan tingkat signifikansi 0,578 di atas 0,05. Berdasarkan nilai tersebut, maka hipotesis ke tujuh dalam penelitian ini ditolak karena indeks hutang (leverage) tidak mampu membedakan laporan keuangan yang telah dimanipulasi dan laporan keuangan yang tidak dimanipulasi.

8.Variabel Total Accrual to Total Assets (TATA) mampu membedakan antara laporan keuangan yang diduga telah dimanipulasi dan diduga tidak dimanipulasi.

Hasil uji analisis diskriminan terhadap variabel Total Accrual To Total Asset (TATA) menunjukkan nilai koefisisen sebesar 0,439 dengan nilai signifikan sebesar 9,947E-6 atau 0,00000947 di bawah 0,05. Berdasarkan hasil pengujian tersebut, hipotesis ke delapan dinyatakan diterima karena indeks TATA mampu membedakan laporan keuangan yang telah dimanipulasi dan laporan keuangan yang tidak dimanipulasi.

\section{Simpulan}

1) Variabel Days Sales Receivable Index (DSRI) mampu membedakan antara laporan keuangan yang diduga telah dimanipulasi dan diduga tidak dimanipulasi.

2) Variabel Gross Margin Index (GMI) mampu membedakan antara laporan keuangan yang diduga telah dimanipulasi dan diduga tidak dimanipulasi.

3) Variabel Assets Quality Index (AQI) tidak mampu membedakan antara laporan keuangan yang diduga telah dimanipulasi dan diduga tidak dimanipulasi.
4) Variabel Sales Growth Index (SGI) mampu membedakan antara laporan keuangan yang diduga telah dimanipulasi dan diduga tidak dimanipulasi.

5) Variabel Depreciation Index (DEPI) tidak mampu membedakan antara laporan keuangan yang diduga telah dimanipulasi dan diduga tidak dimanipulasi.

6) Variabel Sales General and Administrative Expenses Index (SGAI) tidak mampu membedakan antara laporan keuangan yang diduga telah dimanipulasi dan diduga tidak dimanipulasi.

7) Variabel Leverage Index (LVGI) tidak mampu membedakan antara laporan keuangan yang diduga telah dimanipulasi dan diduga tidak dimanipulasi.

8) Variabel Total Accrual to Total Assets (TATA) mampu membedakan antara laporan keuangan yang diduga telah dimanipulasi dan diduga tidak dimanipulasi.

9) Persamaan atau fungsi diskriminan yang terbentuk dalam penelitian ini yaitu :

Z-score $=-4,423+2,014 \mathrm{DSRI}+0,965 \mathrm{GMI}+1,730 \mathrm{SGI}+$ 12,741 TATA.

\section{Referensi}

Beneish, M. D. (1999). The Detection of Earnings Manipulation. Financial Analysts Journal, 55(5), 24-36. https://doi.org/10.2469/faj.v55.n5.2296

Fraud Examiners Manual. (2011). Association of Certified Fraud Examiners: Vol. I (pp. 1-15).

Ghozali, I. (2011). Aplikasi Analisis Multivariate Dengan Program IBM SPSS 19 edisi 5. BP Universitas Dipenogoro.

Hantono. (2018). Analisis Pendeteksian Financial Statement Fraud Dengan Pendekatan Model Beneish Pada Perusahaan Bumn. Going Concern : Jurnal Riset Akuntansi, 13(3), 254-269. https://doi.org/10.32400/gc.13.03.20170.2018

Indriantoro, N., \& Supomo, B. (2014). Metodologi Penelitian Bisnis untuk Akuntansi dan Manajemen. Yogyakarta: BPFE.

Priantara, D. (2013). Fraud Auditing and Investigation. Jakarta: Mitra Wacana Media.

PT Bursa Efek Indonesia. (n.d.). Retrieved March 14, 2020, from https://www.idx.co.id/

Roxas, B. (2008). Entrepreneurial Knowledge and it's Effect on Entrepreneurial Intention. In School of Managament and Marketing.

Tarjo, \& Herawati, N. (2015). Application of Beneish M-Score Models and Data Mining to Detect Financial Fraud. Procedia - Social and Behavioral Sciences, 211(2015), 924-930. https://doi.org/10.1016/j.sbspro.2015.11.122

Widodo, A., Yusiana, R., \& Anggi, S. (2017). How E-marketing and Trust Influence Online Buying decision: A Case Study of Mataharimall.com in Bandung. Journal of Social Sciences \& Humanities, 25(S), 107-114. 